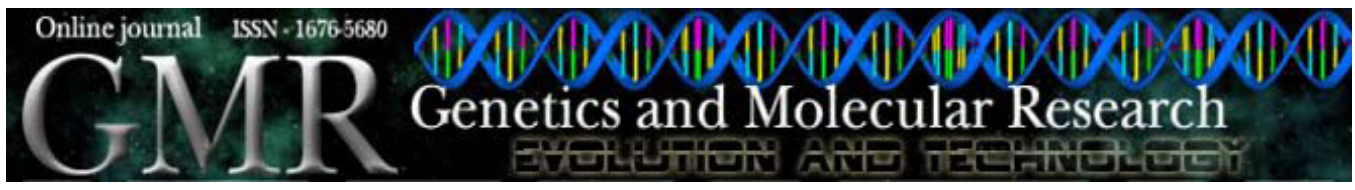

\title{
Isolation of a novel lipase from a metagenomic library derived from mangrove sediment from the south Brazilian coast
}

\author{
G.H. Couto, A. Glogauer, H. Faoro, L.S. Chubatsu, E.M. Souza and \\ F.O. Pedrosa \\ Departamento de Bioquímica e Biologia Molecular, \\ Universidade Federal do Paraná, Curitiba, PR, Brasil \\ Corresponding author: F.O. Pedrosa \\ E-mail: fpedrosa@ufpr.br
}

Genet. Mol. Res. 9 (1): 514-523 (2010)

Received November 20, 2009

Accepted January 4, 2010

Published March 23, 2010

\begin{abstract}
A novel gene coding for a LipA-like lipase with 283 amino acids and a molecular mass of $32 \mathrm{kDa}$ was isolated and characterized from a metagenomic library prepared from mangrove sediment from the south Brazilian coast. LipA was $52 \%$ identical to a lipolytic enzyme from an uncultured bacterium and shared only low identities $(\leq 31 \%)$ with lipases/esterases from cultivable microorganisms. Phylogenetic analysis showed that LipA, together with an orthologous protein from an uncultured bacterium, forms a unique branch within family I of true lipases, thereby constituting a new lipase subfamily. Activity determination using crude extracts of Escherichia coli bearing the $\operatorname{lip} A$ gene revealed that this new enzyme has a preference for esters with short-chain fatty acids $(\mathrm{C} \leq 10)$ and has maximum activity against $p$-nitrophenyl-caprate (chain length $\mathrm{C} 10,0.87 \mathrm{U} / \mathrm{mg}$ protein). The optimum $\mathrm{pH}$ of LipA was 8.0, and the enzyme was active over a temperature range of 20 to $35^{\circ} \mathrm{C}$, with optimum activity against $p$ nitrophenyl-butyrate at $35^{\circ} \mathrm{C}$ and $\mathrm{pH} 8.0$.
\end{abstract}

Key words: Metagenome; Lipase; Mangrove sediment 


\section{INTRODUCTION}

Mangroves are biologically important and productive marine ecosystems located along tropical and subtropical coastlines and estuaries. The microbial communities present in mangrove sediment participate actively in various ecological processes and are responsible for major nutrient transformations, which are crucial for the health and balance of the ecosystem (Alongi et al., 1993; Holguin et al., 2001). Despite numerous studies on bacterial productivity and activity within mangrove ecosystems, little is known about their genetic and metabolic diversity (Alongi, 1988; Holguin et al., 2001).

Molecular phylogenetic studies have shown that only a small fraction of bacterial diversity present in environmental samples (e.g., soil, $0.1-1 \%$ ) are readily cultivable using traditional pure culture-based techniques (Amann et al., 1995). The not-yet-cultivated bacteria can serve as a potential source of new biocatalysts and compounds as they may possess a large diversity of enzymes adapted to different environmental conditions.

Metagenomics allows culture-independent genomic analysis of microbial communities contained in an environmental sample circumventing difficulties associated with conditions for microbial cultivation (Amann et al., 1995; Handelsman et. al., 1998). Metagenomic analysis involves the isolation of DNA from an environmental sample, cloning of the DNA into a suitable vector and transforming the clones into a host bacterium, usually an Escherichia coli strain (Handelsman, 2004). The resulting transformants can be screened for expression of enzyme activities (functional-based screening), or plasmid DNA can be sequenced randomly (sequencebased screening) (Handelsman, 2004).

Bacteria produce different classes of lipolytic enzyme, including lipases (EC 3.1.1.3) and carboxylesterases (EC 3.1.1.1), which catalyze the hydrolysis and synthesis of long $(\geq 10)$ and short chain $(\leq 10)$ acylglycerols, respectively (Arpigny and Jaeger, 1999). These enzymes constitute an important group of biocatalysts with numerous biotechnological applications owing to their useful features, such as their broad substrate specificity, high enantioselectivity, stability in organic solvents, and no requirement for cofactors (Jaeger and Reetz, 1998; Jaeger and Eggert, 2002). On the basis of identity and biological properties, bacterial lipases have been classified into eight families, with the largest (family I) being further divided into seven subfamilies (Arpigny and Jaeger, 1999). However, novel lipolytic enzymes have been isolated and identified from metagenomes from various environments, and new families have been proposed (Henne et al., 2000; Lee et al., 2006; Kim et al., 2009).

In this study, we isolated a gene encoding a new lipolytic enzyme by functional screening of a metagenomic library derived from mangrove sediment sample. We present the sequence analysis of the lipA gene and biochemical characterization of the lipase activity using crude extract of E. coli carrying the recombinant plasmid pUC-LipA, which bears the lipase activity.

\section{MATERIAL AND METHODS}

\section{Bacterial strains, plasmids and growth condition}

Escherichia coli DH5 $\alpha$ (Invitrogen) and E. coli EPI300-T1R (Epicentre) were used in this study. Fosmid pCC2Fos (Epicentre) and pUC19 (Invitrogen) were used as vectors to con- 
struct the metagenomic library and for subcloning, respectively. E. coli cells were grown in liquid or solid Luria-Bertani (LB) medium at $37^{\circ} \mathrm{C}$, supplemented with $100 \mu \mathrm{g} / \mathrm{mL}$ ampicillin or 12.5 $\mu \mathrm{g} / \mathrm{mL}$ chloramphenicol as selectable markers for the vectors pUC19 or pCC2Fos, respectively.

\section{Sample collection and extraction of metagenomic DNA}

The sediment sample was collected from a mangrove forest composed mainly of red mangrove (Rhizophora mangle), located in the estuarine region of the Maciel River, in Pontal do Paraná, PR, Brazil. The sample was taken superficially $(0-5 \mathrm{~cm}$ depth) during the period of low tide at the GPS coordinates $25^{\circ} 33^{\prime} 42^{\prime \prime} \mathrm{S} / 48^{\circ} 25^{\prime} 16.1^{\prime \prime} \mathrm{W}$. Immediately after sampling, the sediment was stored on ice and subjected to DNA extraction based on an indirect lysis method described by Hardeman and Sjöling (2007), in which prokaryotic cells are separated from the sediment by low-speed centrifugation, followed by cell lysis. This procedure yielded a crude DNA preparation still contaminated with humic compounds. For further purification, DNA samples were loaded on a $0.8 \%$ low melting point (LMP) agarose gel in $1 \mathrm{X}$ TAE buffer, and electrophoresis was performed overnight at $1.5 \mathrm{~V} / \mathrm{cm}$. DNA fragments with molecular weight higher than $20 \mathrm{~kb}$ were excised from the gel and then subjected to a second electrophoresis as before. Finally, high-molecular weight (HMW) DNA fragments were isolated from LMP agarose gel by the phenol method (Sambrook et al., 1989). DNA concentration was measured using the Quant-iT dsDNA BR Assay kit with a Qubit fluorimeter, as described by the manufacturer (Invitrogen).

\section{Metagenomic library construction and screening for lipolytic activity}

A metagenomic DNA library was constructed using the CopyControl Fosmid Library production kit (Epicentre) according to manufacturer instructions. Briefly, the purified HMW DNA was end-repaired with end-repair enzyme mix (Epicentre) and then ligated to the copycontrol pCC2Fos vector (Epicentre). Lambda packaging extracts were added to the ligation mixture, and infection of E. coli EPI300-T1R was performed according to the manufacturer protocol. The E. coli transformants grown in LB agar medium with $12.5 \mu \mathrm{g} / \mathrm{mL}$ chloramphenicol at $37^{\circ} \mathrm{C}$ for $24 \mathrm{~h}$ were individually transferred to 96 -well microtiter plates with LB liquid medium, yielding 2400 clones. After overnight growth at $37^{\circ} \mathrm{C}, 50 \%$ glycerol was added and the cells stored at $-20^{\circ} \mathrm{C}$. For lipolytic activity screening, clones were replicated with a 96-pin array onto LB agar medium containing $1 \%$ emulsified tributyrin, $0.1 \%$ gum arabic, $12.5 \mu \mathrm{g} / \mathrm{mL}$ chloramphenicol and $0.001 \%$ arabinose, which increased the fosmid copy number. Cells were grown at $37^{\circ} \mathrm{C}$ for $48 \mathrm{~h}$ and colonies with a clear hydrolysis halo were selected.

\section{Subcloning and screening of the secondary library}

DNA from a clone showing lipolytic activity on tributyrin agar plates was purified using the alkaline lysis protocol (Sambrook et al., 1989). The fosmid DNA was partially digested with Sau $3 \mathrm{AI}$, and fragments ranging from 5 to $8 \mathrm{~kb}$ were isolated using $0.8 \%$ LMP agarose gel. DNA fragments were ligated into a BamHI-linearized pUC19 vector and transformed into E. coli $\mathrm{DH} 5 \alpha$. This sublibrary contained approximately 500 clones, which were screened for lipolytic activity on LB agar medium with $100 \mu \mathrm{g} / \mathrm{mL}$ ampicillin and $1 \%$ tributyrin, as before. 


\section{DNA sequencing}

A clone from the sublibrary expressing lipolytic activity (pUC-LipA) was selected for DNA sequencing. For this, a collection of derivative plasmids containing EZ-Tn5 $<\mathrm{KAN}-2>$ randomly inserted was obtained by using an in vitro transposon insertion reaction with EZTn5<KAN-2 $>$ Insertion Kit (Epicentre).

Ninety-six clones were sequenced using primers specific for the EZ-Tn $5<\mathrm{KAN}-2>$ transposon ends by the dideoxy-chain termination method (Dye Terminator Cycle Sequencing Kit, GE HealthCare) with an ABI 377 automated sequencer (Applied Biosystems). Sequence assembly and contig editing were performed with the CodonCode Aligner program (CodonCode Corporation). The open-reading frame (ORF) was identified with the ORF Finder tool provided by the National Center for Biotechnology Information (NCBI). The translated ORFs were compared to known sequences deposited in the non-redundant protein databases (www. ncbi.nlm.nih.gov) using the BLAST program (Altschul et al., 1990). Multiple alignments were performed with the CLUSTAL W program (Thompson et al., 1994), and phylogenetic analysis was done using the MegAlign program from the Lasergene software package (DNAStar Inc.).

\section{Protein analysis}

SDS-PAGE was performed on $10 \%$ polyacrylamide $(w / v)$ gels, essentially as described by Laemmli (1970). For MALDI-TOF analysis, a spot corresponding to LipA was excised from an SDS-PAGE gel and treated as described (Westermeier and Naven, 2002). Mass spectra were acquired using a MALDI-TOF-MS Autoflex spectrometer (Bruker Daltonics), and peak lists were created using FlexAnalysis 2.0 (Bruker Daltonics). Protein concentration of the cell extracts was determined by the Bradford method using bovine serum albumin as standard (Bradford, 1976).

An overnight culture of E. coli DH5 $\alpha$ containing the recombinant plasmid pUC-LipA was centrifuged at $5000 \mathrm{~g}$ for $10 \mathrm{~min}$. The pellet was resuspended in $50 \mathrm{mM}$ phosphate buffer, $\mathrm{pH} 7.0$, sonicated, and cleared by centrifugation at $10,000 \mathrm{~g}$ for $10 \mathrm{~min}$. The supernatant was recovered for the lipase assays using $p$-nitrophenyl (pNP)-esters as substrates. The reaction mixture contained $66 \mathrm{mM}$ Tris- $\mathrm{HCl}$ buffer, $\mathrm{pH}$ 8.0, 0.6\% Triton X-100, 0.1\% gum arabic and pNP-esters ( $2 \mathrm{mM}$, final concentration). The reaction was started by adding $70 \mu \mathrm{L}$ of the enzyme solution, and the final volume of the reaction mixture was $210 \mu \mathrm{L}$. The formation of pNP was continuously monitored for $20 \mathrm{~min}$ at $30^{\circ} \mathrm{C}$ with a Tecan Infinite M200 microtiter reader at $415 \mathrm{~nm}$. One unit of enzyme activity (U) was defined as the amount of enzyme required to release $1 \mu \mathrm{moL}$ pNP per minute.

Substrate specificity was determined using pNP esterified with fatty acid of different carbon chain lengths: pNP-acetate (C2), pNP-butyrate (C4), pNP-valerate (C5), pNP-caproate (C6), pNP-caprate (C10), pNP-laurate (C12), pNP-myristate (C14), pNP-palmitate (C16), and pNP-stearate $(\mathrm{C} 18)$. Optimum temperature was determined in the range of $20-40^{\circ} \mathrm{C}$. Thermostability was determined by incubating LipA containing extracts at various temperatures $\left(20^{\circ}\right.$, $25^{\circ}, 30^{\circ}, 35^{\circ}, 40^{\circ}, 45^{\circ}, 50^{\circ}, 55^{\circ} \mathrm{C}$ ) for $30 \mathrm{~min}$, and then measuring the residual activity. The optimum $\mathrm{pH}$ for LipA was determined at $\mathrm{pH}$ ranging from 3 to 11 at $348 \mathrm{~nm}$ using the following buffers: $50 \mathrm{mM}$ acetate/sodium acetate (pH 3.0-5.5), $50 \mathrm{mM}$ MES (pH 5.5-7.0), $50 \mathrm{mM}$ HEPES (pH 7.0-7.5), $50 \mathrm{mM}$ glycine/ $\mathrm{NaOH}$ (pH 7.5-11.0), and $50 \mathrm{mM}$ Tris- $\mathrm{HCl}$ (pH 6.8-8.4). 


\section{RESULTS AND DISCUSSION}

\section{Extraction of sediment DNA}

For extraction of metagenomic DNA from the mangrove sediment, an indirect method was used. The size distribution of the DNA fragments obtained by this method contained molecules from 3 to $22 \mathrm{~kb}$ (Figure 1A). With regard to purity, the isolated DNA appeared to be contaminated with sediment compounds, mainly humic substances as indicated by the brownish color of the recovered DNA solution. Humic substances strongly interfere with cloning procedures because they inhibit enzymatic reactions such as restriction enzyme digestion, Taq polymerase amplification, ligation and transformation (Tsai and Olson, 1992; Tebbe and Vahjen, 1993). To remove these contaminants and also select HMW DNA fragments suitable for fosmid cloning, crude DNA was submitted to two rounds of agarose gel electrophoresis purification (Figure 1B). This procedure resulted in removal of all visible contaminants without further fragmentation of DNA. A yield of about 528 ng per gram sediment (wet weight) was obtained after the purification step.
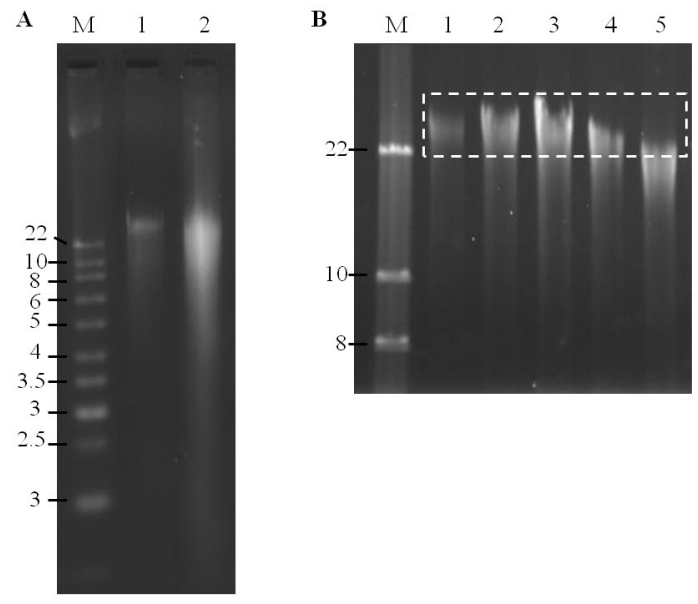

Figure 1. Purification of DNA from mangrove sediment. A. $1 \%$ agarose gel electrophoresis of mangrove DNA. Lane M: Molecular weight markers indicated in $\mathrm{kb}$; lanes 1 and 2: 0.25 and $0.5 \mu \mathrm{g}$, respectively, of DNA isolated by the indirect method. B. Purification and sizing of mangrove sediment DNA by $0.8 \%$ LMP agarose gel electrophoresis. Lane M: Molecular weight markers indicated in $\mathrm{kb}$; lanes 1-5, excised gel slices (dotted box) containing purified mangrove sediment DNA. DNA was stained with ethidium bromide.

\section{Construction and characterization of the metagenomic fosmid library}

The DNA isolated from mangrove sediment was used to construct a fosmid library comprising 2400 clones, which were maintained in E. coli EPI300-T1R. Restriction analysis of 24 randomly picked clones showed insert sizes between 22 and $30 \mathrm{~kb}$ (data not shown). The $E$. coli clones were subjected to functional screening for lipolytic activity on a tributyrin agar plate. A positive clone, named pCC2-Lip, was isolated. The fosmid-encoded activity was confirmed by re-screening in the same substrate after isolation and retransformation of pCC2- 
Lip into E. coli $\mathrm{DH} 5 \alpha$. A sublibrary of approximately 500 clones containing smaller inserts ( $\sim 5$ $\mathrm{kb}$ ) was constructed in the pUC19 plasmid in order to identify the putative lipase gene within pCC2-Lip. A positive clone with high tributyrin hydrolysis activity (pUC-LipA) was selected and its $5.9 \mathrm{~kb}$ insert was completely sequenced.

Sequence analyses revealed three orfs in this fragment (Figure 2): orfl codes for a protein similar to KP-43 peptidase from the soil actinobacteria Arthrobacter sp FB24 (YP_832954) (64\% similarity, 49\% identity); orf2 codes for a protein similar to a lipase of an uncultured bacterium (ACJ13070) (67\% similarity, 52\% identity), and orf3 is not complete and the C-terminus of the coded protein is similar to an adenylate/guanylate cyclase from the sulfate-reducing bacterium Desulfatibacillum alkenivorans AK-01 (YP_002430692) (68\% similarity, 49\% identity). Interestingly, these Gram-positive species are commonly associated with degradation of aromatic compounds in contaminated areas (So and Young, 1999; Joynt et al., 2006). Transposon insertional mutagenesis showed a complete loss of lipolytic activity only when the putative lipase coding gene was disrupted (data not shown), thus confirming that this gene is functional. Therefore, the lipase gene was named lipA.

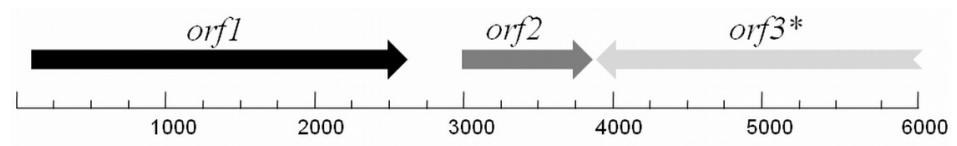

\section{pUC-LipA (5920 bp)}

Figure 2. Physical map of plasmid pUC-LipA expressing lipolytic activity. Three orfs with conserved domains and similarity to annotated genes were identified: orf1 codes for a protein similar to a KP-43 peptidase of Arthrobacter sp FB24 (YP_832954) (64\% similarity, 49\% identity, E value $4^{\mathrm{e}-173}$ ); orf2 codes for a protein similar to a lipase of an uncultured bacterium (ACJ13070) (67\% similarity, 52\% identity, E value $1^{\mathrm{e}-72}$ ), and orf3 codes for a protein similar to an adenylate/guanylate cyclase of Desulfatibacillum alkenivorans AK-01 (YP_002430692) (68\% similarity, 49\% identity, E value $2^{\mathrm{e}-142}$. The closest homologues were identified by BLASTP analyses. The asterisk indicates a partial orf.

The gene lipA is $852 \mathrm{bp}$ long and codes for a protein of 283 amino acid residues with a molecular weight of 32,252 Da and a pI of 5.95. Amino acid sequence search against the NCBI nonredundant protein database showed that LipA is related (52\% identity) to an uncharacterized putative lipase identified in activated sludge bioreactor metagenome (GenBank accession No. ACJ13070) (Table 1). Lower identities $(\leq 31 \%)$ were found with lipases from known microorganisms such as the fungal lipase from Aspergillus clavatus NRRL 1 and lipase from the unusual bacterium Gemmata obscuriglobus, a representative of the Planctomycetales, which possesses a membrane-bound nucleoid and is a model organism to study the evolutionary origin of the eukaryotic nucleus (Lee et al., 2009).

LipA has a conserved alpha/beta hydrolase fold (Nardini and Dijkstra, 1999), which is present in a wide variety of enzymes whose activities rely mainly on a catalytic triad usually formed by Ser, Asp and His residues (Ollis et al., 1992). However, instead of the conserved pentapeptide Gly-X-Ser-X-Gly containing the active serine residue, LipA has the motif AlaHis-Ser-Met-Gly (positions 94 to 98). This motif is found in a small cluster of highly conserved bacterial lipases grouped in the subfamilies I.4 and I.5, which are exclusive to mesophiles and moderately thermophiles of the Bacillus genus, respectively (Arpigny and Jaeger, 1999). 
Table 1. Comparison of LipA isolated from sediment mangrove metagenome with homologous proteins.

\begin{tabular}{|c|c|c|c|c|}
\hline Protein & Source & GenBank accession No. & \%Identity ${ }^{\mathrm{a}}$ & Reference \\
\hline LipA & Uncultured bacterium & - & - & This study \\
\hline Lipase & Uncultured bacterium & ACJ13070 & 52 & Unpublished results ${ }^{\mathrm{a}}$ \\
\hline Hypothetical protein & Podospora anserina DSM 980 & XP_001903948 & 27 & Unpublished results $^{b}$ \\
\hline $\begin{array}{l}\text { Esterase/lipase/ thioesterase } \\
\text { family active site }\end{array}$ & $\begin{array}{l}\text { Gemmata obscuriglobus } \\
\text { UQM } 2246\end{array}$ & ZP_02733109 & 31 & Unpublished results ${ }^{\mathrm{c}}$ \\
\hline YALIOE31515p & Yarrowia lipolytica CLIB122 & XP_504639 & 31 & Dujon et al., 2004 \\
\hline Putative triacylglycerol lipase & Aspergillus clavatus NRRL 1 & XP_001272340 & 26 & Fedorova et al., 2008 \\
\hline Hypothetical protein & Gibberella zeae PH-1 & XP_390196 & 25 & Unpublished results $^{\mathrm{d}}$ \\
\hline Hypothetical protein & $\begin{array}{l}\text { Penicillium chrysogenum } \\
\text { Wisconsin } 54-1255\end{array}$ & XP_002568242 & 27 & van den Berg et al., 2008 \\
\hline Triacylglycerol lipase & Aspergillus fumigatus Af293 & XP 746728 & 25 & Nierman et al., 2005 \\
\hline
\end{tabular}

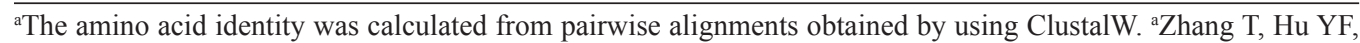
Liu ZP and Zhu BL. ' Espagne E, Lespinet O, Malagnac F, DaSilva C, et al. 'Ward N. dAnonymous.

A phylogenetic analysis based on the amino acid sequences of 35 bacterial lipolytic enzymes representing the 9 different families (Figure 3) (Arpigny and Jaeger, 1999; Lee et al., 2006) showed that LipA and the lipase from an uncultured sludge bioreactor bacterium form a unique branch, located between the subfamily I.5 and I.2 branches, of family I of true lipases. These results suggest that LipA is member of a new subfamily within the family I of lipases.

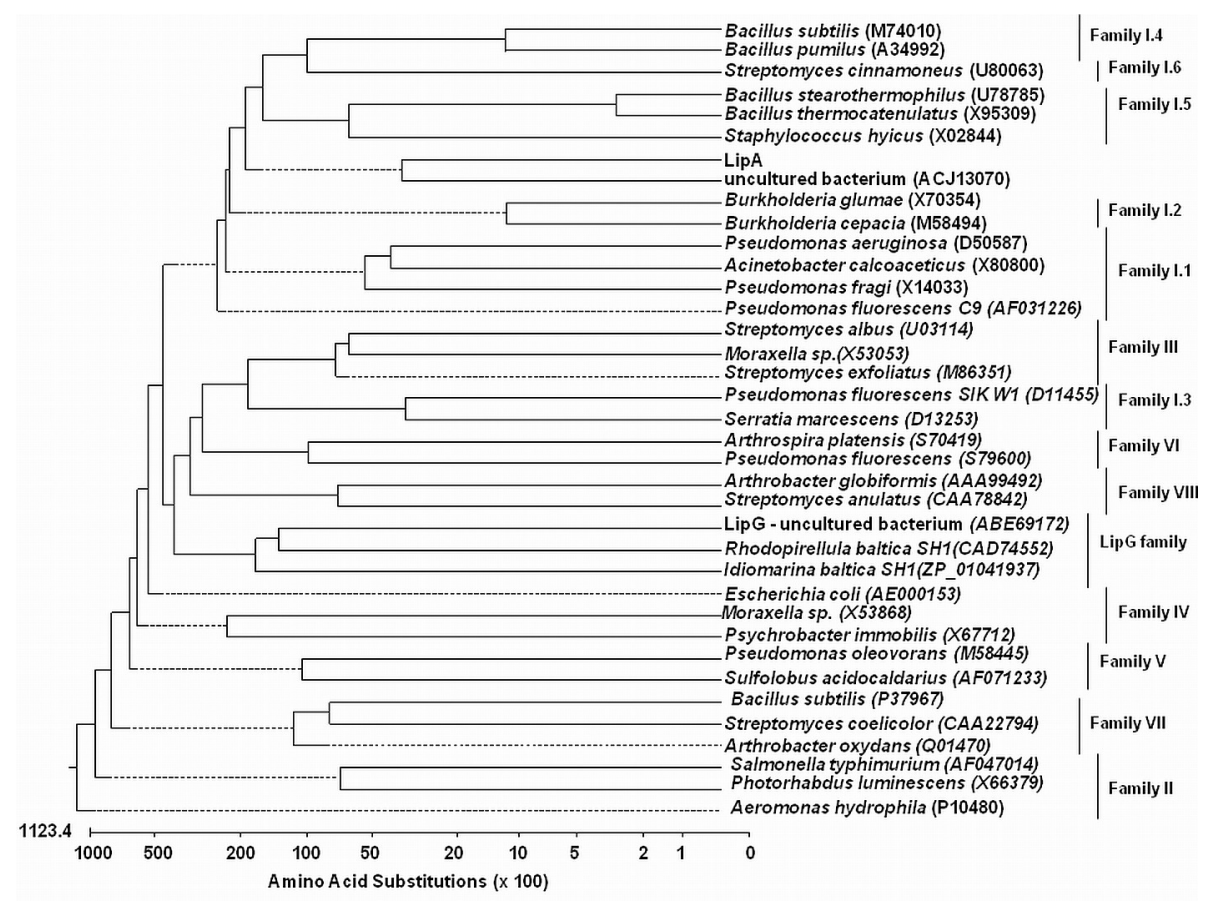

Figure 3. Phylogenetic tree based on amino acid sequence of LipA, and 35 lipolytic enzymes representing 9 different families. The lipase families were defined according to Arpigny and Jaeger (1999) and Lee et al. (2006). The dendrogram was constructed by the neighbor-joining method with the MegAlign program of the DNA-Star software package (Lasergene). The scale indicates the number of amino acid substitutions per site. 


\section{Enzyme assays}

The metagenome-derived lipA gene was amplified, cloned into an expression vector $\mathrm{pET} 18 \mathrm{~b}+$ and overexpressed in E. coli BL21( $\lambda \mathrm{DE} 3)$ pLysS. A MALDI-TOF analysis of an excised spot from the overexpressed protein separated by SDS-PAGE confirmed the enzyme identity (data not shown). However, the overexpressed LipA protein was completely insoluble under several conditions tested (data not shown). We decided to determine the lipolytic activity in the cell extracts from E. coli DH5 $\alpha /$ pUC-LipA. As a control, extracts of DH $5 \alpha /$ pUC19 were prepared under the same conditions, and no lipase/esterase activity was detected under the conditions used.

First, we tested for substrate specificity of LipA using several pNP-esters with acyl chains of different lengths. As shown in Figure 4A, maximum hydrolytic activities were found when pNP-caprate (chain length $\mathrm{C} 10,0.87 \mathrm{U} / \mathrm{mg}$ protein) was used as substrate. A decrease in activity was observed as the length of the fatty acid chains increased further: the activity of LipA for pNPstearate (C18) was only $18 \%$ of that for pNP-caprate. These results indicate that LipA can hydrolyze a wide range of pNP-ester substrates with a preference for short-chain fatty acids $(\mathrm{C} \leq 10)$.
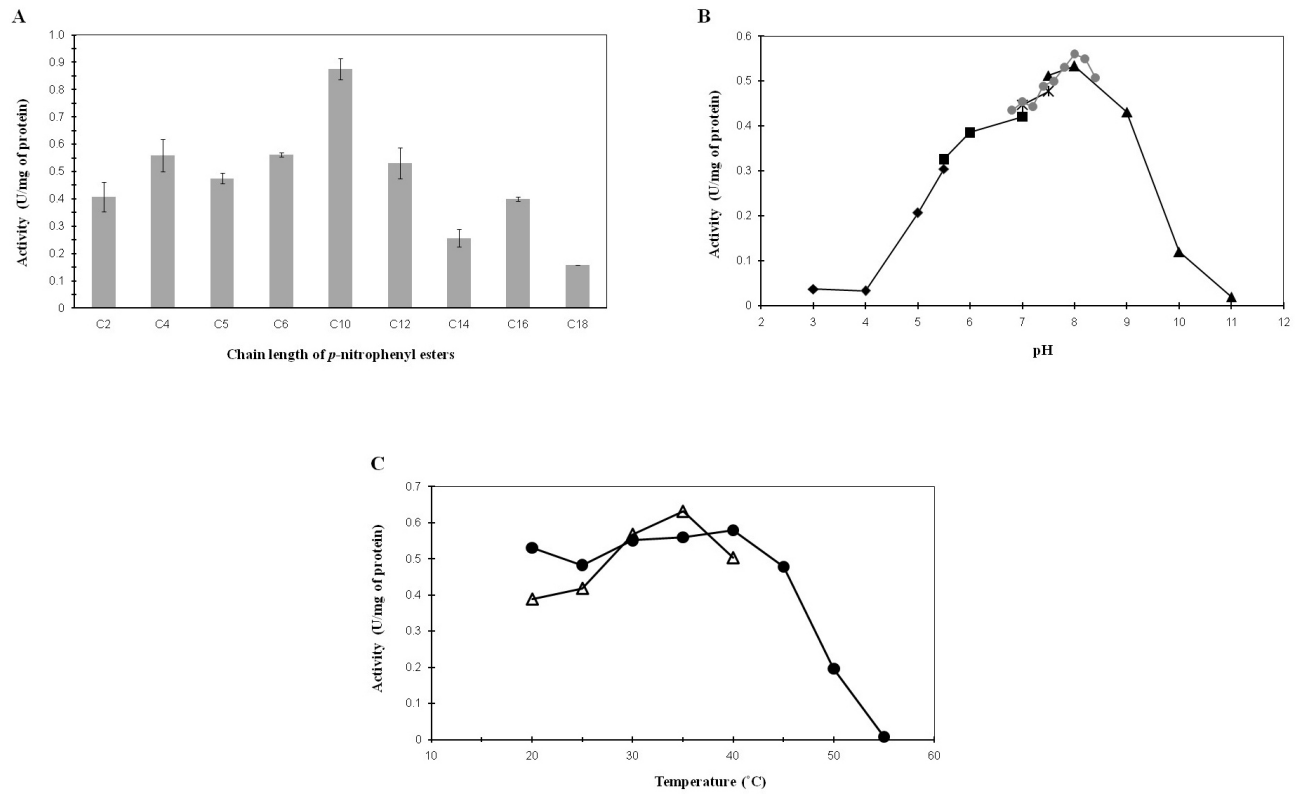

Figure 4. Lipolytic assays with the cell extracts from Escherichia coli DH5 $\alpha /$ pUC-LipA. A. Substrate specificity of LipA for $p$-nitrophenyl (pNP)-esters with different fatty acid chain. The lipase activity of the soluble cell extract was assayed at $30^{\circ} \mathrm{C}$ with $50 \mathrm{mM}$ Tris- $\mathrm{HCl}, \mathrm{pH} 8.0$. The chain length of pNP-esters is expressed as the carbon numbers of fatty acid moiety. B. Effect of $\mathrm{pH}$ on LipA activity. Enzyme activity was determined for each $\mathrm{pH}$ at $30^{\circ} \mathrm{C}$ using pNP-butyrate as substrate. The buffer solutions were: $\mathrm{pH}$ 3.0-5.5: $50 \mathrm{mM}$ acetate/sodium acetate buffer (lozenges); pH 5.5-7.0: $50 \mathrm{mM}$ MES buffer (squares); $\mathrm{pH}$ 7.0-7.5: $50 \mathrm{mM}$ HEPES buffer (crosses); $\mathrm{pH}$ 7.5-11.0: $50 \mathrm{mM}$ glycine/ $\mathrm{NaOH}$ buffer (triangles); $\mathrm{pH}$ 6.8-8.4: $50 \mathrm{mM}$ Tris-HCl buffer (circles). C. Effect of temperature on activity (triangles) and thermal stability (circles) of LipA. Enzyme activity was determined at each temperature under standard assay conditions using pNP-butyrate as substrate. The effect of the temperature on LipA stability was determined by pre-incubating the cell extract in $50 \mathrm{mM}$ Tris- $\mathrm{HCl}$ buffer, $\mathrm{pH} 8.0$, for 30 min at temperature range of $20-55^{\circ} \mathrm{C}$ and then determining the residual activity. Activity values are means of duplicate assays. 
The effect of $\mathrm{pH}$ on LipA activity was determined using pNP-butyrate as substrate in the $\mathrm{pH}$ range from 3 to 11 (Figure 4B). The optimum $\mathrm{pH}$ for LipA was 8.0 using either $50 \mathrm{mM}$ Tris- $\mathrm{HCl}(0.56 \mathrm{U} / \mathrm{mg})$ or $50 \mathrm{mM}$ glycine $/ \mathrm{NaOH}$ buffer $(0.53 \mathrm{U} / \mathrm{mg})$. It is interesting to note that the enzyme possesses a significant activity over a broad $\mathrm{pH}$ range (pH 7.0 to 9.0).

The effect of temperature and thermal stability on LipA was determined also using pNP-butyrate as substrate at $\mathrm{pH} 8.0$ in the temperature range of 20 to $40^{\circ} \mathrm{C}$ (Figure $4 \mathrm{C}$ ). The highest activity was found at $35^{\circ} \mathrm{C}$. At lower temperatures $\left(20^{\circ} \mathrm{C}\right)$, LipA still had $61 \%$ of its maximal activity, but temperatures above $35^{\circ} \mathrm{C}$ caused a clear decrease in activity. To examine the thermal stability of LipA, we incubated the crude cell extract for $30 \mathrm{~min}$ at temperatures ranging from 20 to $55^{\circ} \mathrm{C}$ and measured its residual activity at $30^{\circ} \mathrm{C}$. The enzyme retained $82-$ $95 \%$ of maximal activity from 20 to $45^{\circ} \mathrm{C}$. However, the stability of the enzyme decreased sharply when the temperature of incubation was higher than $45^{\circ} \mathrm{C}$ : no residual activity was recovered after $30 \mathrm{~min}$ of incubation at $55^{\circ} \mathrm{C}$.

In conclusion, a novel lipase was identified using an activity-based screening of a metagenomic library constructed from mangrove sediment DNA. Sequence analyses revealed limited identities with other lipolytic enzymes from cultivated microorganisms, and phylogenetic analysis suggests that LipA together with uncultured bacterium lipase (ACJ13070) is a member of a new subfamily of bacterial lipases within family I.

The studies on substrate specificity demonstrated that LipA had the catalytic ability to hydrolyze substrates with short- or medium-sized carbon chains $(\leq 10 \mathrm{C})$. The results confirm that not-yet-cultivated bacteria from mangrove environments are a potential source for novel biocatalysts.

\section{ACKNOWLEDGMENTS}

We thank Valter A. de Baura, Roseli Prado and Julieta Pie for technical support, and Paulo da Cunha Lana for support in the collection of sediment samples. Research supported by CNPq-Instituto do Milênio, PRONEX-Fundação Araucária, CNPq, and CAPES.

\section{REFERENCES}

Alongi DM (1988). Bacterial productivity and microbial biomass in tropical mangrove sediments. Microb. Ecol. 15: 59-79. Alongi DM, Christoffersen P and Tirendi F (1993). The influence of forest type on microbial-nutrient relationships in tropical mangrove sediments. J. Exp. Mar. Biol. Ecol. 171: 201-223.

Altschul SF, Gish W, Miller W, Myers EW, et al. (1990). Basic local alignment search tool. J. Mol. Biol. 215: 403-410.

Amann RI, Ludwig W and Schleifer KH (1995). Phylogenetic identification and in situ detection of individual microbial cells without cultivation. Microbiol. Rev. 59: 143-169.

Arpigny JL and Jaeger KE (1999). Bacterial lipolytic enzymes: classification and properties. Biochem. J. 343 (Pt 1): 177-183.

Bradford MM (1976). A rapid and sensitive method for the quantitation of microgram quantities of protein utilizing the principle of protein-dye binding. Anal. Biochem. 72: 248-254.

Dujon B, Sherman D, Fischer G, Durrens P, et al. (2004). Genome evolution in yeasts. Nature 430: 35-44.

Fedorova ND, Khaldi N, Joardar VS, Maiti R, et al. (2008). Genomic islands in the pathogenic filamentous fungus Aspergillus fumigatus. PLoS Genet. 4: e1000046.

Handelsman J (2004). Metagenomics: application of genomics to uncultured microorganisms. Microbiol. Mol. Biol. Rev. 68: 669-685.

Handelsman J, Rondon MR, Brady SF, Clardy J, et al. (1998). Molecular biological access to the chemistry of unknown soil microbes: a new frontier for natural products. Chem. Biol. 5: R245-R249.

Hardeman F and Sjöling S (2007). Metagenomic approach for the isolation of a novel low-temperature-active lipase from 
uncultured bacteria of marine sediment. FEMS Microbiol. Ecol. 59: 524-534.

Henne A, Schmitz RA, Bomeke M, Gottschalk G, et al. (2000). Screening of environmental DNA libraries for the presence of genes conferring lipolytic activity on Escherichia coli. Appl. Environ. Microbiol. 66: 3113-3116.

Holguin G, Bashan Y and Vazquez P (2001). The role of sediment microorganisms in the productivity, conservation, and rehabilitation of mangrove ecosystems: an overview. Biol. Fertil. Soils 33: 265-278.

Jaeger KE and Reetz MT (1998). Microbial lipases form versatile tools for biotechnology. Trends Biotechnol. 16: 396-403. Jaeger KE and Eggert T (2002). Lipases for biotechnology. Curr. Opin. Biotechnol. 13: 390-397.

Joynt J, Bischoff M, Turco R, Konopka A, et al. (2006). Microbial community analysis of soils contaminated with lead, chromium and petroleum hydrocarbons. Microb. Ecol. 51: 209-219.

Kim EY, Oh KH, Lee MH, Kang CH, et al. (2009). Novel cold-adapted alkaline lipase from an intertidal flat metagenome and proposal for a new family of bacterial lipases. Appl. Environ. Microbiol. 75: 257-260.

Laemmli UK (1970). Cleavage of structural proteins during the assembly of the head of bacteriophage T4. Nature 227: 680-685.

Lee KC, Webb RI and Fuerst JA (2009). The cell cycle of the planctomycete Gemmata obscuriglobus with respect to cell compartmentalization. BMC Cell Biol. 10: 4.

Lee MH, Lee CH, Oh TK, Song JK, et al. (2006). Isolation and characterization of a novel lipase from a metagenomic library of tidal flat sediments: evidence for a new family of bacterial lipases. Appl. Environ. Microbiol. 72: 7406-7409.

Nardini M and Dijkstra BW (1999). Alpha/beta hydrolase fold enzymes: the family keeps growing. Curr. Opin. Struct. Biol. 9: 732-737.

Nierman WC, Pain A, Anderson MJ, Wortman JR, et al. (2005). Genomic sequence of the pathogenic and allergenic filamentous fungus Aspergillus fumigatus. Nature 438: 1151-1156.

Ollis DL, Cheah E, Cygler M, Dijkstra B, et al. (1992). The alpha/beta hydrolase fold. Protein Eng. 5: 197-211.

Sambrook J, Fritsch EF and Maniatis T (1989). Molecular Cloning: a Laboratory Manual. 2nd edn. Cold Spring Harbor Laboratory Press, Cold Spring Harbor.

So CM and Young LY (1999). Isolation and characterization of a sulfate-reducing bacterium that anaerobically degrades alkanes. Appl. Environ. Microbiol. 65: 2969-2976.

Tebbe CC and Vahjen W (1993). Interference of humic acids and DNA extracted directly from soil in detection and transformation of recombinant DNA from bacteria and a yeast. Appl. Environ. Microbiol. 59: 2657-2665.

Thompson JD, Higgins DG and Gibson TJ (1994). CLUSTAL W: improving the sensitivity of progressive multiple sequence alignment through sequence weighting, position-specific gap penalties and weight matrix choice. Nucleic Acids Res. 22: 4673-4680.

Tsai YL and Olson BH (1992). Detection of low numbers of bacterial cells in soils and sediments by polymerase chain reaction. Appl. Environ. Microbiol. 58: 754-757.

van den Berg MA, Albang R, Albermann K, Badger JH, et al. (2008). Genome sequencing and analysis of the filamentous fungus Penicillium chrysogenum. Nat. Biotechnol. 26: 1161-1168.

Westermeier R and Naven T (2002). Proteomics in Practice: A Laboratory Manual of Proteome Analysis. In: Gel Digestion (Westermeier R and Naven T, eds.). Wiley-VCH, Weinheim, 261. 